the mechanisms by which people make decisions about right or wrong. Here it becomes peculiarly hard - and at the same time especially important - to resist the 'naturalistic fallacy' of inferring what ought to be from what is. Science may be able to tell us why some values are more easily held than others. But it cannot tell us whether taking the easy path in terms of which values we espouse is the right thing to do.

In fact, it provides us with a worked example to the contrary. The scientific endeavour itself is founded on values which natural selection would have seemed unlikely to foist on a bunch of violent, gregarious upright apes. Science tries to place no trust in authority; to some extent, society has to. Science tries to define its membership on the basis of inclusion, rather than exclusion; work on altruism suggests, worryingly, that communities more normally need an outgroup to form against. Science insists on the value of truth even when it is inconvenient or harmful; most people's beliefs tend to reinforce their self-interest.

\section{Natural value}

\section{The economic downturn might be the best time to include ecosystem services in the real economy.}

W orldwide momentum seems to be growing for an approach to environmental protection based on the 'ecosystem services' that nature provides for humans. These can range from watersheds filtering drinking water and forests sequestering carbon, to marshes dissipating the fury of storms. As long as the marketplace treats such services as free goods, proponents argue, the value of what nature does for humanity will effectively be set to zero and nature will continue to be trashed. But if the market could somehow be made to price the services appropriately, all those forests, streams, lakes, prairies and seashores would suddenly acquire real economic value, and people would have incentives to preserve them.

The ecosystem services approach clearly has great potential. Indeed, it is a natural extension of the market-based carbon tax or cap-and-trade approaches now being implemented to curb carbon emissions, in that it tackles environmental externalities historically ignored by the global economy. This month, moreover, a special issue of the Ecological Society of America's journal Frontiers in Ecology and the Environment offers some badly needed hard science on the subject. In one paper, for example, computer modelling of land use in the Willamette Basin in Oregon shows that commercial development ceases to be the most rational use of land when the simulation incorporates even conservatively priced payments for the carbon sequestration the land provides.

This special issue is just one of several recent developments that seem to herald ecosystem services' entry into mainstream scientific and political thinking. The Economics of Ecosystems and Biodiversity project funded by the European Union is collecting scientific evidence on the "economic consequences of biodiversity loss" until 31 March. The goal is to assemble a toolkit of techniques and information for those who want to do empirical ecosystem valuations of their own.

Elsewhere, last December the US Congress created an Office of
In this unnaturalness lies the great strength of science. It is from this it derives its power as a way of understanding the world. And this is also what allows it, at its best, to resist, not reinforce, mores and prejudices that pose as truths of nature. This demanding, artificial code is what gives engaged, passionate and all-too-fallible human beings the collective power to produce results that are dispassionate, objective and reliable. And if science stays true to that code, it can act as a stern restraint on anyone seeking to go from the study of how people evolved to conclusions about how they should be treated now - to go, that is, against the values that both Darwin and Lincoln espoused.

Science can never prove humans alike in dignity, or equally deserving under the law; that is a truth that cannot be discovered. Like the ideals of malice towards none and charity towards all, it is something that must be made real through communal will.

Ecosystem Services and Markets in the Department of Agriculture, along with a government-wide Conservation and Land Management Environmental Services Board to advise on incentives for ecosystem services. And last November, a meeting in Malaysia kicked off a United Nations-sponsored Intergovernmental Science-Policy Platform on Biodiversity and Ecosystem Services patterned after the agency's influential Intergovernmental Panel on Climate Change.

If such efforts are to succeed, however, and if ecosystem services are ever going to be successfully integrated into the regular economy, the scheme will have to be founded on even more hard science. Distributed sensing efforts such as the US

"Destroying ecosystems for short-term benefit is like killing the cow for its meat, when one might keep from starving by drinking its milk for years."

National Science Foundation's National Ecological Observatory Network will be invaluable in this regard. But science policy-makers will need to make ecosystem monitoring, research, analysis and simulation a high priority in general - and on an ongoing basis. Granted, it will be difficult to find money for such activities in the current economic downturn. But they could provide a fair number of jobs. Monitoring tasks such as checking sediment traps and nitrogen levels in streams require many boots on the ground, for example, and streambed restoration requires many more.

The downturn also highlights perhaps the most worrying consequence of putting prices on the services provided by nature: it will make everything more expensive. This is not a politically palatable move at any time, much less now. But the whole point of the ecosystem services approach is that it saves everyone money in the long run. The damage that Hurricane Katrina inflicted on Louisiana in 2005 was a dramatic example of how ecosystem services - in this case, storm-buffering wetlands - are often cheaper to maintain than they are to live without. As governments launch large infrastructure projects to stimulate their economies, they should fold ecosystem services into the budget analyses. Destroying many ecosystems for short-term economic benefit is like killing the cow for its meat, when one might keep from starving by drinking its milk for years to come. Now is not the time to slaughter the cow. 